\title{
Misreading a pastoral property regime in the Logone floodplain, Cameroon
}

\author{
Mark Moritz $^{1}$
}

\begin{abstract}
This is a response to an article by Haller et al. (2013) in Ecology and Society titled "How fit turns into misfit and back: institutional transformations of pastoral commons in African floodplains." In this response, I argue that Haller et al.'s description of the pastoralists' management of common-pool grazing resources in the Logone floodplain of Cameroon is incorrect in a number of ways. I summarize the findings from our longitudinal and interdisciplinary study to show that current pastoralists' management of common-pool grazing resources in the floodplain is efficient, equitable, and sustainable. Specifically, ecological research contradicts Haller et al.'s proposition that resource degradation is due to overgrazing in a situation of open access. This is an important point to clarify because pastoralists are often wrongly accused of overgrazing the range.
\end{abstract}

Key Words: common-pool resources; floodplains; pastoralists; property regimes; rent seeking

\section{INTRODUCTION}

This is a response to an article in Ecology and Society by Haller et al. (2013). In this response, I argue that Haller et al.'s (2013) description of the pastoralists' management of common-pool grazing resources in the Logone floodplain of Cameroon is incorrect.

In a comparative study of pastoral commons in four African floodplains, Haller et al. (2013) argue that in precolonial times, there was fit between institutions and the common-pool resources governed, but that there currently is a misfit because states have undermined common property regimes, replacing them with state and private ownership of natural resources, resulting in a tragedy of the commons. One of the case studies where this transformation is supposed to have happened is the Logone floodplain in Cameroon. My colleagues and I have studied the pastoral system in that floodplain for the last 20 years. Whereas we initially developed an argument of nomadic contract (Moritz et al. 2002), we further developed our ideas and showed that pastoralists are efficiently, equitably, and sustainably managing common-pool grazing resources in a situation of open access (Moritz et al. 2013a,b, 2014a,b).

I argue that Haller et al. (2013) have misread the pastoral system in the Logone floodplain, where our studies have shown that there is currently a good fit between local, regional, national, and international institutions and the common-pool grazing resources governed. In addition, I would like to bring into question the claim of Haller et al. (2013) that there was an "institutional fit" in the precolonial past. This claim may be valid from the perspective of Kotoko, who were in control of the system, but I would interpret it as an inequitable system aimed at extracting rents and protecting the interests of one ethnic group over those of others. Most importantly, I discuss the findings of longitudinal studies that show that pastoralists' open access to common-pool grazing resources does not lead to overgrazing and a tragedy of the commons. It is important to offer this correction because, too often, pastoralists are blamed for rangeland degradation, even though no empirical evidence is offered to support that argument. This is also the case with Haller et al.'s
(2013) argument, in which they propose to examine institutional fit with the ecosystem, but do so without a study or references to studies of the ecosystem.

In this response, I first briefly describe the social-ecological system of the Logone floodplain. Second, I describe the findings of our longitudinal and interdisciplinary study of mobile pastoralists in the floodplain. Third, I challenge the arguments that there was a fit between institutions and the resource system there in the past, and that today there is a misfit. Finally, I draw some general conclusions with regard to the problem of misreading pastoral property regimes.

\section{THE LOGONE FLOODPLAIN}

The Logone floodplain in the Far North Region of Cameroon is an excellent example of a coupled human and natural system because there are strong linkages between the social, ecological, and hydrological systems (Moritz et al. 2016). The intra- and interannual variations in the area, depth, and duration of seasonal flooding have direct and indirect effects on ecosystems, lives, and livelihoods of the people living in the floodplain, including fishers, herders, and farmers. For pastoralists, the floodplain is one of the most important dry season grazing lands in the Chad basin. Each year, thousands of pastoralists from Cameroon and neighboring Chad, Niger, and Nigeria trek with $>200,000$ cattle to the floodplain when the water retreats in November to exploit the excellent quantity and quality of the grasslands (Seignobos 2000). At the start of the rainy season in June, pastoralists leave the floodplain and return to the rainy season grazing lands in Cameroon or neighboring countries.

Since the 1970s, there have been major changes in the flooding regime of the Logone floodplain, with direct and indirect consequences for the coupled systems of the floodplain. Most dramatically, the large-scale Maga dam and a dike along the Logone River severely reduced flooding in the 1980s. The Maga dam had major consequences for pastoralists because forage production directly depends on flooding patterns. A few years after the construction of the dam, the species composition in the grasslands in the parts of the floodplain that were most affected 
by the decrease in flooding started to change (Scholte 2005). When forage production declined, the floodplain could support fewer cattle, and many pastoralists left for other grazing areas in Chad, Nigeria, and the Central African Republic. Some left for good, whereas others returned later when the Waza Logone project started a reflooding project in the 1990s and most systems gradually rebounded, although not to the pre-dam state (Loth 2004, Scholte 2005).

Notably, we found that pastoralists adjusted the number of cattle to the available resources as the quality and quantity of forage improved because of the reflooding efforts (Scholte et al. 2006). In other words, the grazing pressure closely tracked the increase in biomass after reflooding, and there were no indications of overuse or underuse of the grazing resources in the floodplain (Scholte 2005, Scholte et al. 2006).

\section{LONGITUDINAL STUDY OF A PASTORAL SYSTEM}

Although open access to common-pool resources has been equated with a tragedy of the commons (Hardin 1968, Ostrom 1990), we have found that this is not the case for mobile pastoralists in the Logone floodplain in the Far North Region of Cameroon. On the contrary, we have described pastoralists' management of open access to common-pool grazing resources as a self-organizing complex adaptive system in which mobile pastoralists distribute themselves over the available common-pool grazing resources without conflicts (Moritz et al. 2013b, 2014a).

Since 2008, my colleagues and I have conducted a longitudinal and interdisciplinary study of mobile pastoralists in the Far North Region of Cameroon. The goal was to explain how mobile pastoralists manage common-pool grazing resources in a situation of open access in the Logone floodplain. Our hypothesis was that management worked as a complex adaptive system and that, as a result of independent decision making at the level of the individual, pastoralists would distribute themselves over the available grazing resources such that the distribution of grazing pressure matches the distribution of grazing resources at the population level, as in an ideal free distribution (Fretwell and Lucas 1969). We have described our findings in a number of publications. First, we used ethnographic methods to describe how open access works in the Logone floodplain. We found that all pastoralists have the same rights to use grazing lands regardless of ethnicity, nationality, seniority, or socioeconomic status. Pastoralists emphatically argued that access is free and open for everyone (Moritz et al. 2013b). Second, we used spatial methods to document an ideal free distribution of pastoralists in the floodplain (Moritz et al. 2014a,b). Third, we used agent-based modeling to show that it is relatively easy for pastoralists making independent movement decisions to achieve an ideal free distribution at the population level (Moritz et al. 2015a). Fourth, we showed that economic inequality did not undermine the system of open access (Moritz et al. 2015b). Fifth, we discussed the implications of our findings for the governance of rangelands (Moritz et al. 2013a).

I have argued elsewhere that the pastoral system in the Logone floodplain is best described as an open property regime in which open access is not the absence of rules; open access is the rule (Moritz 2016). In pastoral systems where mobile pastoralists use common-pool grazing resources that are highly variable in space and time, an open property regime is appropriate because it is equitable, efficient, and sustainable. In open property regimes, everyone has equal rights and no one can be excluded. Moreover, open property regimes work as complex adaptive systems in which independent decision making of highly mobile households results an efficient distribution of grazing pressure over the available resources. I have also described four other case studies with similar open property regimes (Moritz 2016): the Tuareg in northern Mali (Berge 2000), the Kababish Arabs in Sudan (Asad 1970), the Turkana in northwest Kenya (Gulliver 1951), and the Pashtun in western Afghanistan (Glatzer 1977). Thus, the case of pastoralists' management of open access to common-pool grazing resources in the Logone floodplain is not unique.

Pastoralists in the Logone floodplain are not living in a world of only pastoralists; they share the floodplain with fishers and farmers who use other common-pool resources such as fish and fields. Thus, there are multiple, overlapping property regimes that govern different common-pool resources in the floodplain. While the open property regime efficiently, equitably, and sustainably regulates access to grazing resources among pastoralists, it does not regulate access to these resources between pastoralists and other user groups. There are conflicts between pastoralists and fishers over use of other resources in the floodplain, as described by Haller et al. (2013).

\section{MISFIT IN THE PRECOLONIAL PERIOD}

The Logone floodplain is not only home to pastoralists, but also to Kotoko and Musgum fishers. Kotoko are considered the firstcomers in the floodplain, and during the precolonial period the Kotoko chiefs ruled a large part of the floodplain and devised institutions that governed access to and use of common-pool resources. In the last 100 years, the Kotoko chiefs have gradually lost power, and privileges have increased for Musgum fishers and Arab pastoralists, who have moved into and settled in the parts of the floodplain that were once ruled by the Kotoko. The loss of power of traditional authorities is not only due to demographic shifts in the floodplain, but also to changes in national policies and politics (Issa 2007). Most recently, processes of democratization and decentralization have fueled party politics and empowered a larger group of citizens and politicians (Socpa 2002), in some cases, at the expense of traditional authorities. The institutional changes that have occurred in the last 100 years have led the Kotoko to lose their monopoly over the management of common-pool resources.

While Haller et al. (2013) argue that the Kotoko institutions regulating access to resources worked well in the past, I would argue that the system was not equitable in the past because the institutions served to protect the interests of the Kotoko over those of other groups. Haller et al. (2013) write that the Kotoko nobles not only managed the fishing resources, but also the grazing resources because they decided when pastoralists could access the pastures. Haller et al. (2013) argue that the Kotoko institutions coordinated the timing of different economic activities in the floodplain and so minimized conflicts and transaction costs between different user groups, for example, between fishers and pastoralists. This is particularly salient when the floods recede and Kotoko fishers use their canals and pastoralists enter the floodplain with their cattle. The canals, which run east-west and may reach $\geq 2 \mathrm{~km}$ in length, block the transhumance routes of pastoralist that run north-south. By 
delaying the entry of pastoralists into the floodplain, Kotoko could finish canal fishing without cattle destroying their canals and threatening their income.

While this is probably the best solution to this conflict of timing, I would argue that by giving pastoralists access to pastures only after the fishing activities in the canals have ended, the Kotoko nobles solved the problem in favor of Kotoko fishers and at the expense of FulBe and Arab pastoralists. Similar inequities existed between Kotoko and Musgum fishers; the former were given priorities with regard to fishing rights and the construction of fishing canals. In short, in the past, the institutions were designed to protect the interests of Kotoko fishers at the expense of other user groups. Moreover, floodplain fisheries are highly productive systems driven by flood dynamics and can be robust to high levels of exploitation (Welcomme and Hagborg 1977). It is likely that fisher populations were well below carrying capacity in the past and that the institutions then were not aimed at sustainable management of fish resources. It appears that the foremost goal of the Kotoko chiefs was not sustainable management of common-pool resources, but rather extracting rent and protecting Kotoko interests.

\section{AN OPEN PROPERTY REGIME}

I next describe the open property regime of pastoralists in the floodplain as I have come to understand it, drawing on a number of my previous publications (Moritz et al. 2013a,b, 2014a,b, Moritz 2016). Given the extensive research of social and ecological systems, I would argue that this description is a more accurate description of the current state of pastoralists' management of common-pool grazing resources in the Logone floodplain than that presented by Haller et al. (2013).

Mobile pastoralists in the region share a strong ethos of open access to common-pool grazing resources. They believe that every pastoralist has the same rights to use grazing lands, regardless of ethnicity, nationality, seniority, or socioeconomic status. Pastoralists emphatically argue that access is free and open for everyone; it does not matter whether pastoralists are coming from Cameroon or Nigeria, whether they are newcomers or old-timers, or whether they are FulBe or Arab. When asked about open access, pastoralists would say as a matter of fact, "na'i non, naa yimBe" (it's [about] cattle, not [about] people) or "nagge nyaamataanagge" (cattle do not eat [other] cattle), meaning that all cattle are equal and have equal access to the pastures (Moritz et al. 2013b). For mobile pastoralists, keeping cattle is not only a way of making a living and a way of life, but one could argue that cattle are life because without them people cannot live as pastoralists. In this sense, to deny cattle access to grazing resources would be to deny pastoralists life. This ethos of open access, which is shared among all mobile pastoralists in the study area, including absentee owners and their hired herders, informs how pastoralists coordinate their movements and use of common-pool grazing resources (Moritz et al. 2013b).

Although pastoralists gain customary rights over campsites after two or three years of consecutive seasonal occupation, these rights do not give pastoralists exclusive access over the common-pool grazing resources surrounding the campsite. Thus, access to grazing lands is open, even when pastoralists have customary rights to campsites within these grazing lands. No one is obliged to ask for permission from traditional or governmental authorities or other pastoralists to set up camp near established campsites. This applies to all pastoralists, including newcomers from other groups or countries. Pastoralists may ask fellow pastoralists whether they can set up camp close by, but this request cannot be refused. Moreover, many pastoralists do not ask or inform their neighbors about site decisions out of principle, not even when they set up camp $250 \mathrm{~m}$ from another campsite. These rules are not limited to the floodplain; they also apply to the rainy season grazing areas in other parts of the Far North Region.

We have referred to this system as management of open access (Moritz et al. 2013b), which we argue is not an oxymoron because there are clear rules about who has access to the common-pool grazing resources (all pastoralists) and who can be excluded (no one). The rules are reaffirmed in everyday practice every time pastoralists set up camps in new sites without asking. The ethos and practice of open access is a form of everyday management that regulates the use of common-pool resources in that there are two important outcomes: the emergence of an ideal free-like distribution of mobile pastoralists in which the distribution of grazing pressure matches the distribution of grazing resources (Moritz et al. 2014a,b), and a lack of major conflict among pastoralists (Scholte et al. 2006). These outcomes require the everyday commitment of pastoralists to the ethos and practice of open access. Pastoralists themselves talk about open access not in terms of an absence of rules, but in terms of rights for all. Moreover, these rules are meaningful to mobile pastoralists: Without access to common-pool grazing resources, they cannot survive in this semi-arid environment (Moritz et al. 2013b). The current pastoral system is highly adaptive and resilient because there is both an ecological fit and an institutional fit. Mobility and open access are critical for sustainable management of common-pool grazing resources that are highly variable in space and time.

\section{INSTITUTIONAL FIT}

It may come as a surprise, but national governments in the Chad basin have generally been supportive of pastoralists' mobility and their open access to common-pool grazing resources. The notion of open access to common-pool grazing resources is thus not limited to mobile pastoralists in the Logone floodplain; national laws and international agreements also support it. It is a good example of nested institutions in which the management system of mobile pastoralists is supported by higher institutions (Ostrom 1990, Ostrom et al. 2002).

First, current laws support open access to common-pool grazing resources. Grazing lands in Cameroon are legally state property (Ordinance 74-1 of 1974). However, the law explicitly gives all pastoralists the right to use these common-pool resources unless the state uses these grazing lands for other purposes such as wildlife conservation or agricultural development projects. National laws thus support pastoralists' open access to grazing lands; provided that pastoralists vaccinate their animals and pay their taxes, they cannot be denied access to these common-pool grazing resources.

Second, national and international policies protect transhumance corridors that allow pastoralists to move between seasonal grazing areas in the Chad basin. The Lake Chad Basin Commission (LCBC) has been supporting the system of open access to common-pool grazing resources since its creation in the 
1960s by the four countries bordering Lake Chad: Cameroon, Chad, Niger, and Nigeria. The LCBC member countries recognize the importance of the livestock for the economy in the Chad basin, and their primary concerns are coordination of veterinary controls and facilitating livestock trade (and thus livestock movements) between countries. In addition, the LCBC aims to regulate and control the use of water and other natural resources in the basin and to initiate, promote, and coordinate natural resource development projects and research. International agreements between LCBC member countries enable freedom of movement for pastoralists in the Chad basin, provided they have vaccinated their animals and paid the local and national taxes. This allows pastoralists from Chad, Niger, Nigeria, Cameroon, and more recently the Central African Republic and Sudan, which joined the LCBC, to travel freely within the Chad basin if they can show their certificate of vaccination and tax receipts.

There are few historical data on pastoralists' management of common-pool grazing resources in the Logone floodplain in the precolonial period. Travel accounts from the 19th century describe pastoralists near the floodplain, but they also describe slave raids and warfare between the Islamic states and their neighbors (Barth 1965). The colonial conquest established a "colonial peace" that opened up the floodplain for pastoralists (Seignobos 2000). The ethno-historical evidence suggests that pastoralists had open access to common-pool grazing resources in the floodplain, and by the 1960s, pastoralists from all over the Diamaré went on transhumance to the Logone floodplain (Mouchet 1960). National laws later affirmed pastoralists' rights of open access to common-pool grazing resources. Thus, instead of dismantling a property regime, I would contend that the state supported an existing open property regime.

\section{ECOLOGICAL FIT}

Haller et al. (2013) suggest that pastures in the Logone floodplain are degrading because pastoralists have open access to commonpool grazing resources. However, in our studies of mobile pastoralists in the Logone floodplain, we have found no evidence of overgrazing or rangeland degradation, i.e., a tragedy of the commons. One of the main reasons is that there is a weak coupling between herbivores and vegetation in the floodplain. The vegetation is controlled by flooding and naturally protected against overgrazing because up to two-thirds of the biomass is stored underground, the floodplain is inaccessible for pastoralists during at least four to six months of the year, and even when accessible, the roots are difficult to graze because of the firm soil (Scholte 2007, Scholte and Brouwer 2008). In other words, flooding, not grazing, determines the vegetation. Moreover, this root bank of perennial grasses generates forage every year after the floods and is comparable to the seed bank of annual grasses in the Sahelian rangelands, in which there is also a weak coupling between herbivores and vegetation (Hiernaux et al. 2016).

Another reason for the absence of a tragedy of the commons is that it is an open system and pastoralists are able to move to wherever the grazing resources are; they are not restricted to one seasonal grazing area. In the five years that we tracked the distribution of pastoralists in our study area in the floodplain using GPS and GIS technology and the distribution of forage using the normalized difference vegetation index (an indicator of the quality and quantity of forage), we found that the former closely matched the latter. In other words, pastoralists effectively distribute themselves over the available resources within the floodplain as in an ideal free distribution (Moritz et al. 2014a). Similarly, we found that when the grasslands in the floodplain recovered after the reflooding project in the 1990s, the increase in grazing pressure closely tracked the increase in biomass (Scholte et al. 2000, 2006). This also suggests that pastoralists distribute themselves over seasonal grazing areas in an ideal free distribution (Moritz et al. 2014b).

Indeed, rangeland degradation occurred in the floodplain in the 1980s, but this was caused by the Maga dam and not by overgrazing. The reduced flooding directly affected forage production, in part via a change in plant species composition in areas most affected by the reduced flooding (Scholte 2005). Perennial species such as Vetiveria nigritana, Echinochloa pyramidalis, and Oryza longistaminata slowly disappeared, whereas annual grasses such as Sorghum arundinaceum increased in areas where flooding was limited. Moreover, on the western edge of the floodplain, which no longer flooded, the grass savannah gradually changed into a dense forest of acacia trees. Both the shift from perennial to annual species and from grass savannah to woody savannah reduced the grazing resources for pastoralists. The annual species that came to dominate the floodplain were of much less value to cattle than the perennial species it replaced. As forage production declined, many pastoralists left for the North Region in Cameroon as well as for Chad, Nigeria, and the Central African Republic. Although there are no reliable data for the pastoralist population in the $1970 \mathrm{~s}$ and 1980s, interviews that we conducted with pastoralists about the changes in transhumance movements indicated that there was a veritable exodus of pastoralists because of the changes in vegetation caused by the dam and the drought. This pasture degradation was driven by the lack of flooding and not by overgrazing caused by institutional changes in management of common-pool grazing resources within the floodplain.

\section{MISREADING PASTORAL PROPERTY REGIMES}

McCay (2002), like Vayda (2009), has argued that theoretical models may prevent researchers from recognizing how users interact with common-pool resources. I would add that McCay's concerns not only apply to Hardin's (1968) "tragedy of the commons" model but also to Ostrom's (1990) "governing the commons" model, which has become the dominant lens with which African pastoral systems have been studied and managed since the 1990s (Peters 1994, Lesorogol 2008).

Haller et al. (2013) are not the only people who have misread pastoral property regimes. A quick review of literature on pastoral systems in the Far North Region of Cameroon shows how models have shaped researchers' interpretations. Researchers have consistently mislabeled pastoral property regimes as common property regimes or as de facto open access because of government interventions leading to breakdown of traditional commons. Most researchers have used the "governing the commons" model that assumes that there is regulation of access to common-pool grazing resources. Requier-Desjardins (2001) and Rouchier et al. (2001), for example, describe the management of common-pool grazing resources as a commons. They argue that even though there is no formal regulation of access, access is regulated through informal negotiations between mobile 
pastoralists on the one hand and farmers and traditional authorities on the other. Rouchier et al. (2001) explicitly label the management of common-pool grazing resources as commons while simultaneously describing a situation of open access.

When the herdsmen are away from their home village, they live in the bush. This space is a common property: it is not privately appropriated and anyone is allowed to use the resources that are on it. It is thus said to be on open access (Hardin 1968). But one can notice that herdsmen are not actually free to graze their cattle wherever they please. Although the lands seem to be open, there exist unwritten rules that define how these 'commons' should be used, although the land seems to be open (Ostrom 1990). In the context of North Cameroon, the head of the village is responsible for the presence of the herdsmen, who are expected to announce their arrival to the village leader. If tradition has it that the village leaders never refuse access, it is equally habitual, if not compulsory, for the herdsmen to offer money ... (Rouchier et al. 2001:529, emphasis added).

My colleagues and I have described the same system slightly differently and argued that mobile pastoralists had a "nomadic contract" with traditional authorities whereby open access to grazing resources and personal safety were protected by sedentary FulBe authorities in their territory, in exchange for tax and tributes (Moritzet al. 2002). However, we argued that the nomadic contract was about guaranteeing open access for mobile pastoralists, not about excluding them. We gave the example of how the traditional FulBe chief of Mindif argued for mobile pastoralists' open access to common-pool grazing resources in his territory against the wishes of the Mindif-Moulvoudaye AgroPastoral Development Project, which wanted to exclude nomads from the project's grazing blocks in the 1980s (Moritz et al. 2002).

To a certain extent, Rouchier et al. (2001) are correct: commonpool grazing resources are legally state property, and pastoralists make payments to traditional and governmental authorities. However, authorities are not controlling access because no one is refused access. Moreover, Cameroonian law explicitly gives everyone, including foreigners, the right to use these public lands for grazing. The authorities are simply collecting taxes and rents; they are not regulating access (see Rent seeking is not governance).

Haller et al. (2013) have interpreted the introduction of apparent government control in the postcolonial state as the reason for the demise of traditional common property regimes that were present in the precolonial state; this transformation led to de facto open access in that pastoralists may feel that they have access because they pay taxes (Fokou 2010, Haller 2010). I argue that there has been open access to common-pool grazing resources in both preand postcolonial states.

\section{RENT SEEKING IS NOT GOVERNANCE}

It is a common mistake to interpret the extraction of rents as the governance of common-pool resources. In the Logone floodplain, Kotoko authorities are not coordinating pastoralists' use of common-pool grazing resources; they are collecting rents and protecting the interests of fishers.

When we asked mobile pastoralists how they gain access to the common-pool grazing resources in the Logone floodplain, many mentioned that, "herders must ask the traditional Kotoko chief and pay taxes" when they want to set up their camp. Others argued that, "they do not need permission, they just set up camp, and then people will find them for the taxes." The latter statement is a more accurate description of what we have observed in the floodplain: pastoralists do not go to traditional authorities to ask for permission; instead, representatives of the authorities come to the pastoralists to collect taxes. One could argue that the former is the "public transcript" because it shows the authorities in charge, whereas the latter can be considered a form of "hidden transcript" in that it challenges the official version of the relationship between pastoralists and authorities in the floodplain (Scott 1990). The fact that representatives of the authorities come to collect taxes after the pastoralists have set up camps also indicates that this is not about management of common-pool resources, i.e., organizing who can set up camp when and where, but primarily about revenue generation and rent-seeking by governmental, municipal, and traditional authorities (Moritz et al. 2015b).

There is also no evidence that the collection of taxes by the Kotoko authorities regulates access to common-pool grazing resources (Moritz et al. 2013b). The transhumance tax that pastoralists pay in each municipality where they set up camp ranges from approximately 10,000 FCFA (\$20 USD) to 12,000 FCFA (\$24 USD) per herd. On average, pastoralists stay in three municipalities per year, resulting in 30,000 FCFA (\$60 USD) in transhumance tax, which seems high, and pastoralists complain about it. However, using very conservative estimates of a herd of 50 cattle with an average value of 100,000 FCFA (\$200 USD) per animal, the transhumance tax amounts to $0.6 \%$ of their total property value and only $3 \%$ of pastoralists' annual income from cattle sales (Moritz 2003). Moreover, although pastoralists always complain about taxes (and who doesn't?), I have never heard that pastoralists change their transhumance routes to avoid municipalities because of taxes. Thus, there is no indication that taxes regulate access or function as a disincentive, even for poorer pastoralists.

Previously, we wrote that pastoralists announce their presence in the territory by paying a visit to the traditional authorities (Moritz et al. 2002). We now know that pastoralists simply set up camp wherever they want because the authorities will show up to collect the transhumance tax. Leaders of pastoral groups may visit the traditional authorities and pay tribute, but they do this to solidify their political position within their community, rather than to gain access to common-pool grazing resources for their followers. The leaders of pastoral groups we interviewed referred to the payments to traditional authorities as ceede huDO (literally, money for grass) and ceede sabur (literally, money for soap), which suggests that it is a small token gift rather than a large tribute. More importantly, we found, both in the 1990s and in 2008-2012, that no one is refused access, not even pastoralists who explicitly refused to pay even a nominal amount. Again, there is no evidence of regulation through taxation.

\section{WHERE IS THE ECOLOGY?}

Some time ago, Vayda and Walters (1999) wrote a commentary titled Against Political Ecology in which they argued that many political ecologists were studying politics without studying the ecology, and that if political ecologists want to make claims about 
how politics shapes environmental change, they should at least study the ecology (for a review of this discussion see Walker 2005). A similar problem exists in the study of social-ecological systems. There is a considerable body of literature on social-ecological systems in African floodplains, and while the coupling of systems is always acknowledged, most research focuses on only one of the systems, and couplings with other systems are then considered context.

This critique also applies to Haller et al.'(2013) publication, which is based on an ambitious comparative study that examines the institutional context of the management of natural resources in African floodplains, including the Logone floodplain. The results of the case studies and the comparative analysis have been published in multiple articles and books (e.g., Haller 2010, 2012). However, because the team consisted solely of social scientists, it remains unclear what the effects of institutions are on natural resources. While it is understandable that the team consisted of social scientists (the study's focus was on institutions), it is also problematic because claims are made about the effectiveness of these institutions in terms of managing natural resources.

Haller et al. (2013) write that they combine a range of theoretical approaches, including institutional analysis and ecological approaches, to examine how pastoralists in four African floodplains manage common-pool resources. However, no studies of the ecosystem have been conducted. The authors mention that they "have collected information on ecological studies" and have visited the areas with specialists, e.g., botanists, ecologists, and veterinary officers, but that is not the same as conducting an ecological study or reviewing ecological studies (Fynn et al. 2015). The authors rely mostly on reports from locals about changes in the ecosystem, which indicate a change in species composition of grasslands from higher to lower quality species, and increasing variability in rainfall patterns and associated flooding patterns. However, it is unclear whether we should take these observations at face value because no ecological or climate data are presented to support these claims about changes in the ecosystem.

Nevertheless, Haller et al. (2013:3-4) conceptualize floodplains as social-ecological systems and write, "One cannot separate the institutional context from the ecosystem context: these are interlinked or to put in other words, they have coevolved and formed the ecosystem in place," and, "Institutional fit has to be understood as embedded within specific social ecological contexts." However, the authors use several alternative terms to describe the social-ecological systems of the floodplains, including but not limited to: social-ecological systems, socialnatural system, and anthropogenic ecosystem setting, suggesting the lack of a clear conceptualization of social-ecological systems used in the analysis. Notably, the term "political environment" is always listed separately from the social-ecological system, suggesting that politics are not an analytical part of the socialecological system of these floodplains when they should be.

Haller et al. (2013) argue that by integrating institutional analysis and ecological approaches, they will be able to study how institutions lead to sustainable management of natural resources. However, because no ecological studies are conducted, that goal cannot be achieved. It is only if studies of the social system are combined with studies of the ecological system that we are able to evaluate that argument. For example, if Haller et al. (2013) had conducted a longitudinal study of the changes in vegetation in the floodplain or reviewed the literature (Scholte et al. 2000, Scholte 2005, 2007), they would have found that grassland dynamics are driven by flooding, not by grazing, and that after the reflooding project in the 1990s, pasture quality increased in response to the increase in flooding and that there was no decrease because of overgrazing. They would then have to conclude that flooding, and not institutional change, is the main driver in the floodplain.

Elsewhere, we have argued that the conceptual approach of coupled human and natural systems in which the emphasis is on developing an integrated and quantitative model of social, ecological, and hydrological systems will allow researchers to examine not only how systems shape each other, but also how much (Moritz et al. 2016). A coupled systems approach that examines the dynamics of social and ecological systems allows researchers to answer the question of institutional fit and advance the understanding of the dynamics of African floodplains. Our studies of the pastoral ecosystem in the floodplain indicate that open property regimes are a good institutional fit for resource systems in which common-pool grazing resources are highly variable in space and time and abiotically driven (Scholte et al. 2006, Moritz et al. 2014a).

\section{CONCLUSION}

Normally I do not write responses to articles, but the stakes are high for pastoralists in the Logone floodplain and elsewhere (Davis 2016). Haller et al. (2013) simply repeat the same old story that open access to common-pool grazing resources leads to a tragedy of the commons in pastoral systems. I hope to have shown convincingly that this story is inaccurate and that there is no tragedy. On the contrary, I would argue that the open property regime of mobile pastoralists in the Logone floodplain is equitable, efficient, and sustainable. More importantly, it is not the only such case; there are many other pastoral systems that work in similar ways.

Responses to this article can be read online at: http://www.ecologyandsociety.org/issues/responses. $\mathrm{php} / 9055$

\section{Acknowledgments:}

Our research has been supported by the National Science Foundation (BCS-0748594, DBI-0827256), the National Geographic Society (8306-07), and the Ohio State University. I thank pastoralists in Cameroon for participating in the study; the Center for Research and Development of Pastoralism (CARPA) for research support; the Ministry of Scientific Research and Innovation, the Garoua Wildlife College, and the Higher Institute of the Sahel at the University of Maroua for granting research permission and research affiliation (2008-2013); and Sarah Laborde, Sui Chian Phang, and Paul Scholte for critical feedback on an earlier version of this manuscript. 


\section{LITERATURE CITED}

Asad, T. 1970. The Kababish Arabs: power, authority and consent in a nomadic tribe. C. Hurst and Co., London, UK.

Barth, H. 1965. Travels and discoveries in North and central Africa: being a journal of an expedition undertaken under the auspices of H.B.M.'s government in the years 1849-1855. Keystone Publishing, Philadelphia, Pennsylvania, USA.

Berge, G. 2000. In defence of pastoralism: form and flux among Tuaregs in northern Mali. Centre for Development and the Environment, University of Oslo, Oslo, Norway.

Davis, D. K. 2016. The arid lands: history, power, knowledge. MIT Press, Cambridge, Massachusetts, USA.

Fokou, G. 2010. Tax payments, democracy and rent seeking administrators: common-pool resource management, power relations and conflicts among the Kotoko, Musgum, Fulbe and Choa Arab in the Waza-Logone floodplain (North Cameroon). Pages 121-170 in T. Haller, editor. Disputing the floodplains: institutional change and the politics of resource management in African wetlands. Brill, Leiden, The Netherlands. http://dx.doi. org/10.1163/ej.9789004185326.i-454

Fretwell, S. D., and H. L. Lucas Jr. 1969. On territorial behavior and other factors influencing habitat distribution in birds. Acta Biotheoretica 19(1):16-36. http://dx.doi.org/10.1007/BF01601953

Fynn, R. W. S., M. Murray-Hudson, M. Dhliwayo, and P. Scholte. 2015. African wetlands and their seasonal use by wild and domestic herbivores. Wetlands Ecology and Management 23 (4):559-581. http://dx.doi.org/10.1007/s11273-015-9430-6

Glatzer, B. 1977. Nomaden von Gharjistan: aspekte der wirtschaftlichen, sozialen und politischen Organisation nomadischer Durrani-Paschtunen in Nordwestafghanistan. Franz Steiner, Wiesbaden, Germany.

Gulliver, P. H. 1951. A preliminary survey of the Turkana, a report compiled for the Government of Kenya. University of Cape Town, Cape Town, South Africa.

Haller, T., editor. 2010. Disputing the floodplains: institutional change and the politics of resource management in African wetlands. Brill, Leiden, The Netherlands. http://dx.doi.org/10.1163/ ej. $9789004185326 . \mathrm{i}-454$

Haller, T., editor. 2012. The contested floodplain: institutional change of the commons in the Kafue Flats, Zambia. Lexington Books, Lanham, Maryland, USA.

Haller, T., G. Fokou, G. Mbeyale, and P. Meroka. 2013. How fit turns into misfit and back: institutional transformations of pastoral commons in African floodplains. Ecology and Society 18 (1):34. http://dx.doi.org/10.5751/es-05510-180134

Hardin, G. 1968. The tragedy of the commons. Science 162 (3859):1243-1248. http://dx.doi.org/10.1126/science.162.3859.1243

Hiernaux, P., C. Dardel, L. Kergoat, and E. Mougin. 2016. Desertification, adaptation and resilience in the Sahel: lessons from long term monitoring of agro-ecosystems. Pages 147-178 in R. Behnke and M. Mortimore, editors. The end of desertification? Disputing environmental change in the drylands. Springer, Berlin, Germany. http://dx.doi.org/10.1007/978-3-642-16014-1 6
Issa, S. 2007. Chad's vicinity and ethnic warfare in the Logone and Shari Division (far North Cameroon). Sociologus 57 (1):41-60. [online] URL: http://www.jstor.org/stable/43645588

Lesorogol, C. K. 2008. Contesting the commons: privatizing pastoral lands in Kenya. University of Michigan Press, Ann Arbor, Michigan, USA. http://dx.doi.org/10.3998/mpub.300488

Loth, P., editor. 2004. The return of the water: restoring the Waza Logone floodplain in Cameroon. IUCN, Gland, Switzerland. [online] URL: https://portals.iucn.org/library/node/8382

McCay, B. J. 2002. Emergence of institutions for the commons: contexts, situations, and events. Pages 361-402 in E. Ostrom, T. Dietz, N. Dolšak, P. C. Stern, S. Stonich, and E. U. Weber, editors. The drama of the commons. National Academy Press, Washington, D.C., USA. https://doi.org/10.17226/10287

Moritz, M. 2003. Commoditization and the pursuit of piety: the transformation of an African pastoral system. Dissertation. University of California at Los Angeles, Los Angeles, California, USA. [online] URL: http://www.mandaras.info/MandarasPublishing/ Moritz-2011-Commoditization-and-the-Pursuit-of-Piety.pdf

Moritz, M. 2016. Open property regimes. International Journal of the Commons 10(2):688-708. http://dx.doi.org/10.18352/ijc.719

Moritz, M., B. L. Catherine, A. K. Drent, S. Kari, A. Mouhaman, and P. Scholte. 2013a. Rangeland governance in an open system: protecting transhumance corridors in the Far North province of Cameroon. Pastoralism: Research, Policy and Practice 3(1):26. http://dx.doi.org/10.1186/2041-7136-3-26

Moritz, M., I. M. Hamilton, Y.-J. Chen, and P. Scholte. $2014 a$. Mobile pastoralists in the Logone floodplain distribute themselves in an ideal free distribution. Current Anthropology 55 (1):115-122. http://dx.doi.org/10.1086/674717

Moritz, M., I. M. Hamilton, P. Scholte, and Y.-J. Chen. $2014 b$. Ideal free distributions of mobile pastoralists within multiple seasonal grazing areas. Rangeland Ecology and Management 67 (6):641-649. http://dx.doi.org/10.2111/REM-D-14-00051.1

Moritz, M., I. M. Hamilton, A. J. Yoak, P. Scholte, J. Cronley, P. Maddock, and H. Pi. 2015a. Simple movement rules result in ideal free distribution of mobile pastoralists. Ecological Modelling 305:54-63. http://dx.doi.org/10.1016/j.ecolmodel.2015.03.010

Moritz, M., S. Handa, Y.-J. Chen, and N. Xiao. 2015b. Herding contracts and pastoral mobility in the Far North region of Cameroon. Human Ecology 43(1):141-151. http://dx.doi. org/10.1007/s10745-015-9732-6

Moritz, M., S. Laborde, S. C. Phang, M. Ahmadou, M. Durand, A. Fernandez, I. M. Hamilton, S. Kari, B. Mark, P. Scholte, N. Xiao, and R. Ziebe. 2016. Studying the Logone floodplain, Cameroon, as a coupled human and natural system. African Journal of Aquatic Sciences 41(1):99-108. http://dx.doi. org/10.2989/16085914.2016.1143799

Moritz, M., P. Scholte, I. M. Hamilton, and S. Kari. 2013b. Open access, open systems: pastoral management of common-pool resources in the Chad basin. Human Ecology 41(3):351-365. http://dx.doi.org/10.1007/s10745-012-9550-z 
Moritz, M., P. Scholte, and S. Kari. 2002. The demise of the nomadic contract: arrangements and rangelands under pressure in the Far North of Cameroon. Nomadic Peoples 6(1):124-143. http://dx.doi.org/10.3167/082279402782311013

Mouchet, J. 1960. Enquête entomologique dans le Logone et Chari (13-25 mai 1960). I: Le Foyer de glossines du Logone et Chari. II: L'Anophélisme et les possibilités de lutte antipaludique. III: La Transhumance des "Foulbé" dans les "yaéré”. IRCAM, Yaounde, Cameroon.

Ostrom, E. 1990. Governing the commons: the evolution of institutions for collective action. Cambridge University Press, Cambridge, UK.

Ostrom, E., T. Dietz, N. Dolšak, P. C. Stern, S. Stonich, and E. U. Weber. 2002. The drama of the commons. National Academy Press, Washington, D.C., USA. https://doi.org/10.17226/10287

Peters, P. E. 1994. Dividing the commons: politics, policy and culture in Botswana. University Press of Virginia, Charlottesville, Virginia, USA.

Requier-Desjardins, M. 2001. Elevages et transhumance à l'extrême-nord du Cameroun: une étude des contrats d'accès aux paturages communs, enquêtes en mileu pastoral et essai de modélisation contractuelle. Dissertation. Université de Versailles and CIRAD, Saint-Quentin-en-Yvelines, France.

Rouchier, J., F. Bousquet, M. Requier-Desjardins, and M. Antona. 2001. A multi-agent model for describing transhumance in North Cameroon: comparison of different rationality to develop a routine. Journal of Economic Dynamics and Control 25 (3-4):527-559. http://dx.doi.org/10.1016/s0165-1889(00)00035-x

Scholte, P. 2005. Floodplain rehabilitation and the future of conservation and development: adaptive management of success in Waza-Logone, Cameroon. Dissertation. Leiden University, Leiden, The Netherlands. [online] URL: http://hdl.handle. $\underline{\text { net } / 1887 / 4290}$

Scholte, P. 2007. Maximum flood depth characterizes aboveground biomass in African seasonally shallowly flooded grasslands. Journal of Tropical Ecology 23(1):63-72. http://dx.doi. org/10.1017/S026646740600366X

Scholte, P., and J. Brouwer. 2008. Relevance of key resource areas for large-scale movements of livestock. Pages 211-232 in H. H. T. Prins and F. Van Langevelde, editors. Resource ecology: spatial and temporal dynamics of foraging. Springer, Wageningen, The Netherlands. http://dx.doi.org/10.1007/978-1-4020-6850-8 18

Scholte, P., S. Kari, M. Moritz, and H. Prins. 2006. Pastoralist responses to floodplain rehabilitation in North Cameroon. Human Ecology 34(1):27-51. http://dx.doi.org/10.1007/s10745-005-9001-1

Scholte, P., P. Kirda, S. Adam, and B. Kadiri. 2000. Floodplain rehabilitation in North Cameroon: impact on vegetation dynamics. Applied Vegetation Science 3(1):33-42. http://dx.doi. org/10.2307/1478916

Scott, J. C. 1990. Domination and the arts of resistance: hidden transcripts. Yale University Press, New Haven, Connecticut, USA.
Seignobos, C. 2000. Élevage II: les transhumances. Pages 120-123 in C. Seignobos and O. Iyébi-Mandjek, editors. Atlas de la province Extrême-Nord Cameroun. IRD and MINREST, Paris, France.

Socpa, A. 2002. Démocratisation et autochtonie au Cameroun: trajectoires régionales divergentes. Lit, Münster, Germany.

Vayda, A. P. 2009. Explaining human actions and environmental changes. Rowman AltaMira Press, Lanham, Maryland, USA.

Vayda, A. P., and B. B. Walters. 1999. Against political ecology. Human Ecology 27(1):167-179. http://dx.doi.org/10.1023/ A:1018713502547

Walker, P. A. 2005. Political ecology: Where is the ecology? Progress in Human Geography 29(1):73-83. http://dx.doi. org/10.1191/0309132505ph530pr

Welcomme, R. L., and D. Hagborg. 1977. Towards a model of a floodplain fish population and its fishery. Environmental Biology of Fishes 2(1):7-24. http://dx.doi.org/10.1007/bf00001412 